\title{
Comparative study of the fullness of dwarf Siberian pine seeds Pinus pumila (Pall.) Regel from places of natural growth and collected from plants introduced in northwestern Russia by microfocus X-ray radiography to predict their sowing qualities
}

\section{Anastasia Karamysheva ${ }^{1}$, Lev Trofimuk ${ }^{1,2}$, Nikolay Priyatkin ${ }^{3}$, Mikhail Arkhipov ${ }^{3,4}$, Ludmila Gusakova ${ }^{3}$, Polina Shchukina ${ }^{3,4}$, Nikolay Staroverov ${ }^{5}$, and Nikolay Potrakhov ${ }^{5}$}

${ }^{1}$ Komarov Botanical Institute, Russian Academy of Sciences, ul. Professora Popova, 2, Saint Petersburg, 197376, Russian Federation ${ }^{2}$ Scientific Experimental Station of the Komarov Botanical Institute, Plodovoe Village, Priozersk District, Leningrad Region, Russian Federation ${ }^{3}$ Plant Biophysics Division, Agrophysical Research Institute, Grazhdanskiy pr., 14, Saint Petersburg, 195220, Russian Federation

${ }^{4}$ Crop Science Division, Northwestern Center of Interdisciplinary Research of Problems of Food Maintenance, Shosse Podbel'skogo, 7, Saint Petersburg, 196608, Russian Federation 5Department of Electronic Systems and Devices, The First Electrotechnical University "LETI", ul. Professora Popova, 5, Saint Petersburg, 197376, Russian Federation

Citation: Karamysheva, A., Trofimuk, L., Priyatkin, N., Arkhipov, M., Gusakova, L., Shchukina, P., Staroverov, N., and Potrakhov, N. 2020. Comparative study of the fullness of dwarf Siberian pine seeds Pinus pumila (Pall.) Regel from places of natural growth and collected from plants introduced in northwestern Russia by microfocus $X$-ray radiography to predict their sowing qualities. Bio. Comm. 65(4): 297-306. https://doi.org/10.21638/ spbu03.2020.403

Authors' information: Anastasia Karamysheva, PhD Student, orcid.org/00000003-1109-5810; Lev Trofimuk, Agronomist, orcid.org/0000-0002-1007-5087; Nikolay Priyatkin, PhD, Senior Researcher, orcid. org/0000-0002-5974-4288; Mikhail Arkhipov, Dr. of Sci. in Biology, Professor, Chief Researcher, orcid.org/0000-0002-6903 6971; Ludmila Gusakova, PhD, Leading Researcher, orcid.org/0000-0002-6178-2953; Polina Shchukina, Engineer, orcid.org/00000002-5223-8374; Nikolay Staroverov, PhD Student, orcid.org/0000-0002-4404-5222; Nikolay Potrakhov, Dr. of Sci. in Engineering, Professor, Head of Department, orcid. org/0000-0001-8806-0603

Manuscript Editor: Anton Nizhnikov, Department of Genetics and Biotechnology, Faculty of Biology, Saint Petersburg State University, Saint Petersburg, Russia

Received: March 21, 2020;

Revised: September 12, 2020;

Accepted: September 24, 2020

Copyright: (c) 2020 Karamysheva et al. This is an open-access article distributed under the terms of the License Agreement with Saint Petersburg State University, which permits to the authors unrestricted distribution, and self-archiving free of charge.

Funding: The work was carried out within the framework of state task of Agrophysical Research Institute No. 0667-2019-0013, as well as on the planned topics: "Collections of living plants of the Komarov Botanical Institute (history, modern state, prospects of use)" (No. AAAA-A18-118032890141-4).

Competing interests: The authors have declared that no competing interests exist.

\section{Abstract}

As a result of analysis of the quality of Pinus pumila seeds by the method of microfocus X-ray radiography in combination with the automatic analysis of digital X-ray images, it was found that the best characteristics of individual structures and organs of seeds were demonstrated in samples collected from trees growing at site 71 of BIN RAS; the worst - from seeds taken from South Sakhalin. The seeding qualities of Pinus pumila seed samples were determined by standard methods. Based on analysis of the characteristics of digital Xray images of Pinus pumila seeds, it was found that a seed sample from site 71 BIN RAS was characterized by the high level of embryo area $4.19 \pm 0.49 \mathrm{~mm}^{2}$, maximum embryo to thalus ratio $60.95 \pm 7.45 \%$, high level of endosperm area $23.93 \pm 1.24 \mathrm{~mm}^{2}$, and maximum ratio square of embryo area $9.45 \pm 1.17 \%$. The same sample was characterized by a maximum weight of 1000 seeds and a maximum absolute and soil germination ratio, compared to other samples. The obtained data showed that Pinus pumila seeds collected from plants introduced in northwestern Russia by most parameters are not inferior or are even superior to seeds from the natural range.

Keywords: Dwarf Siberian pine, Pinus pumila, seed quality, X-ray radiography of seeds, seed image analysis, soil germination of seeds

\section{Introduction}

Dwarf Siberian pine (Pinus pumila (Pall.) Regel) is a voiced evergreen plant suitable for greening in single and group planting. It is ornamental and durable, and its seeds are used as food. This pine tolerates the climate of northwestern Russia well. In St. Petersburg and Leningrad region it is an extremely rare plant, promising for horticulture, greening and forestry (Orlova et al., 2019). In the Botanical Garden of Peter the Great in St. Petersburg there is regular seed production of Pinus pumila. These seeds are characterized by a high percentage of full-value seeds and relatively high germination (Orlova et al., 2019; Karamysheva et al., 
2019 C). The plants in the territory of the Scientific Experimental Station "Otradnoe" of the Russian Academy of Sciences $\left(60^{\circ} 48^{\prime} 41.7^{\prime \prime} \mathrm{N} 30^{\circ} 14^{\prime} 17.7^{\prime \prime} \mathrm{E}\right)$ have a regular seed crop. Since the main breeding method of Pinus pumila is by seed, it is important to assess the quality of seeds and study their sowing qualities.

The X-ray radiography method of assessing the quality of forestry seeds is described in detail in both foreign and domestic literature. Based on the method of X-ray radiography, M. Simak and A. Gustafsson (1953) developed a methodology for studying the internal structure of wood seeds in order to analyze the polyembryony of embryos, their individual and geographical variability, as well as the rejection of empty and damaged seeds. Later, Duff (1973) and Belcher (1977) demonstrated the effectiveness of the X-ray method in estimating moisture content and the potential viability of spruce oak acorns. Kamra (1973) showed the effectiveness of X-ray imaging to detect emptiness, hidden insect damage, mechanical damage, and other defects in the study of tropical tree seeds. Further development of the X-ray method made it possible to obtain digital images of forestry seeds and to use modern software tools for their processing and analysis. This made it possible to separate viable and non-viable seeds based on the optical density of their internal structures, as well as to determine their anatomical maturity (Sahlin et al., 1999). The results (Goodman et al., 2005) showed the high information value of the $\mathrm{X}$-ray method in combination with visual determination of the exfoliation of seminal leaves from each other and from the pericarp in assessing the degree of desiccation of oak acorns and predicting their ability to germinate. K. G. Tkachenko (2016) conducted research on X-ray analysis of Abies holophylla, Malus x purpurea and Rosa rugosa seeds. The high information value of the method for evaluation of seed completeness and hidden contamination with pests was shown. The interfaced study of germination and X-ray images of seeds of several species of forest species of Saudi Arabia revealed the high efficiency of X-ray imaging in detecting endosperm underdevelopment (Al Turki and Baskin, 2017).

At the Agrophysical Research Institute (St. Petersburg), Arkhipov et al. (2013) showed the informational content of the method of visual radiographic analysis of digital X-ray images for identification of the fullness of spruce fir seeds. Karamysheva et al. (2019a) did the same for Platycladus orientalis (L.) Franco and Thuja sutchuenensis Franch. In addition, Priyatkin et al. (2018) developed an automatic analysis of digital X-ray images of English oak acorns for detection of microcracks and enzyme-mycosis exhaustion. The relationship between $\mathrm{X}$-ray characteristics and growth indices (sprout length) of sprout oak acorns has been established. The characteristics of the individual structures and organs of Pinus sibirica seeds have been investigated. The method of dif- ferential analysis of digital X-ray images has determined their differences, depending on the region of growth of the mother tree (Karamysheva et al., 2019 B).

The purpose of the current work was to study the fullness of Pinus pumila seeds by microfocus X-ray radiography to predict their sowing qualities. During the study, we planned to: 1) Detect and analyze hidden defects of Pinus pumila seed samples by microfocus X-ray radiography, in combination with automatic analysis of digital X-ray images; 2) Evaluate the weight of the Pinus pumila seeds; 3 ) Determine seed sowing qualities (laboratory germination on artificial substrate) by standard methods; 4) Establish the relationship between the characteristics of digital X-ray images of seeds, their weight and sowing qualities.

\section{Materials and methods}

The objects of research were Pinus pumila seeds obtained from Yuzhno-Sakhalinsk (collected from nature on South Sakhalin in October 2016), collected for the Komarov Botanical Institute RAS in St. Petersburg from sites $71\left(59^{\circ} 58^{\prime} 16.2^{\prime \prime} \mathrm{N} 30^{\circ} 19^{\prime} 35.2^{\prime \prime} \mathrm{E}\right)$ and $98\left(59^{\circ} 58^{\prime} 10.1^{\prime \prime} \mathrm{N}\right.$ $30^{\circ} 19^{\prime} 23.0^{\prime \prime}$ E), collected at Scientific Experimental Station "Otradnoe" of the Komarov Botanical Institute RAS $\left(60^{\circ} 48^{\prime} 43.84^{\prime \prime} \mathrm{N}, 30^{\circ} 14^{\prime} 26.58^{\prime \prime} \mathrm{E}\right.$ ) (collected in the first half of September 2018) and Barguzinsky State Natural Biosphere Reserve named after K. A.Zabelin (collected from nature in Transbaikalia in September 2019).

The assessment of the life condition of the plants from which the seeds were collected was carried out according to the known method (Alekseev, 1989). The height of the plants was determined by a leveler rail. The plant survey was conducted during spring-summer periods 2017-2019.

Pinus pumila seeds obtained from Yuzhno-Sakhalinsk in December 2016 were stored in a refrigerator at a temperature of $0-3^{\circ} \mathrm{C}$ for over 2 years. They were sown in April 2019.

In order to implement the method of microfocus X-ray analysis of seeds, specialists of the Agrophysical Research Institute and First Electrotechnical University "LETI" jointly developed a hardware and software complex based on the mobile X-ray diagnostic device PRGU02 for the control of seed quality (ELTECH-Med, ZAO, St. Petersburg, Russia) (Arkhipov et al., 2009). The magnification coefficient of the image was $3.0 \times$ for $\mathrm{X}$-ray imaging.

Processing of digital images was carried out using Argus-BIO, (software from Argus Soft, Ltd.). Analyzed parameters were: embryo area, $\mathrm{mm}^{2}$; ratio of the areas of embryo to thalus, \%; embryo ellipse index, relative units; area of the endosperm, $\mathrm{mm}^{2}$; relative area of seed cover, $\%$; relative area of the endosperm, \%; relative area of the embryo, \%; ratio of average brightness of embryo to the average brightness of a projection of seed, relative units 
(Arkhipov et al., 2019). Additionally we estimated: fullness of seeds, \%; absolute germination, \%; soil germination ratio, \%; seed viability (TZ), $\%$.

Pinus pumila seeds were sown in April 2019 in boxes with artificial soil consisting of deoxidized peat, sand and vermiculite in a ratio of $2: 1: 1$. Seed sprouting was carried out at a temperature of $16-20^{\circ} \mathrm{C}$ with natural lighting. Each of the test batches contained the number of seeds indicated in the X-ray image. Seeds were sown without prior stratification after treatment with the original multi-component preparation AB-7 (Karamysheva at al., 2019 B, C) developed as part of the study of the processes of adaptation of hardwood and softwood trees in Arctic and sub-Arctic natural and climatic zones in the task of the Department of Science and Innovation of YNAO (state contract No. 01-15/4 of 25 July 2012). The preparation is $A B-7$ - a solution of potassium salts of a number of amino acids, vitamins, plant regulators and minor plant nutrients. This preparation completely replaces the stratification proposed in the literature within 1.5-4 months (McMillan-Browse, 1985; Philippova et al., 2015; Karamysheva at al., 2019 B).

Pinus pumila seeds received from Transbaikalia were sown in April 2020 under the same conditions as all other seeds.

Seed viability was tested by the tetrazolium method (TZ) based on dehydrogenase activity measurement, the level of which was found to correlate with seed viability (Hampton and Tekrony, 1995; Alekseychuk and Laman, 2005).

Statistical analysis was performed using standard ANOVA, statistically significant differences are given at $\mathrm{p}<0.05$. Correlation analysis was performed using nonparametric Spearman criteria. Analysis was performed using MS Excel and Statistica 10 software.

\section{Results and discussion}

Plants in the Botanical Garden of Peter the Great, from which seeds were collected, represent one sample, provided in 1998 from the Botanical Garden-Institute of RAS in Yuzhno-Sakhalinsk on Sakhalin Island, where they were grown from seeds collected on the slopes of the Golovnin volcano on Kunashir Island. The seeds were sprouted in 1993, and the plants were planted permanently in 2004 (site 98) and 2012 (site 71) (Karamysheva et al., 2019 C). The plant Pinus pumila (No. 4) at the Scientific Experimental Station "Otradnoe" BIN RAS was grown from seeds obtained from Yakutia in 1980 and planted in a permanent place in 1999.

Characteristics of Pinus pumila (Pall.) Regel plants, from which seeds were collected, in the Botanical Garden of Peter the Great (St. Petersburg) and at the Scientific Experimental Station "Otradnoe" (Leningrad Region) are presented in Table 1.

\begin{tabular}{|c|c|c|c|}
\hline \multirow[b]{2}{*}{ Parameters } & \multicolumn{3}{|c|}{ Seed collection sites } \\
\hline & $\begin{array}{l}\text { Botanical } \\
\text { Garden } \\
\text { of Peter } \\
\text { the Great, } \\
\text { site } 71\end{array}$ & $\begin{array}{c}\text { Botanical } \\
\text { Garden } \\
\text { of Peter } \\
\text { the Great, } \\
\text { site } 98\end{array}$ & $\begin{array}{l}\text { SES } \\
\text { "Otradnoe", } \\
\text { No. } 4\end{array}$ \\
\hline Age, years & 27 & 27 & 39 \\
\hline Height, m & 1.32 & 1.83 & 2.40 \\
\hline Crown size, $\mathrm{m} \times \mathrm{m}$ & $1.9 \times 3.3$ & $4.0 \times 3.4$ & $2.7 \times 3.7$ \\
\hline Numbers of trunks & 3 & 4 & 2 \\
\hline $\begin{array}{l}\text { Maximal diameter of } \\
\text { trunk, mm }\end{array}$ & 60 & 55 & 90 \\
\hline Dry branches, \% & 2 & 3 & 5 \\
\hline $\begin{array}{l}\text { Seeding in } 2017 . \\
\text { (numbers of strobiles) }\end{array}$ & 5 & 2 & I \\
\hline $\begin{array}{l}\text { Seeding in } 2018 . \\
\text { (numbers of strobiles) }\end{array}$ & 21 & 1 & 9 \\
\hline $\begin{array}{l}\text { Seeding in } 2019 . \\
\text { (numbers of strobiles) }\end{array}$ & 17 & 4 & 12 \\
\hline $\begin{array}{l}\text { Seeding in } 2020 . \\
\text { (numbers of strobiles) }\end{array}$ & 15 & 3 & - \\
\hline $\begin{array}{l}\text { Current annual } \\
\text { growth in 2016, mm }\end{array}$ & $71 \pm 20$ & $70 \pm 22$ & $144 \pm 42$ \\
\hline $\begin{array}{l}\text { Current annual } \\
\text { growth in 2017, mm }\end{array}$ & $62 \pm 16$ & $99 \pm 38$ & $153 \pm 40$ \\
\hline $\begin{array}{l}\text { Current annual } \\
\text { growth in 2018, mm }\end{array}$ & $70 \pm 23$ & $81 \pm 32$ & $112 \pm 37$ \\
\hline $\begin{array}{l}\text { Current annual } \\
\text { growth in 2019, mm }\end{array}$ & $67 \pm 27$ & $102 \pm 35$ & $97 \pm 32$ \\
\hline
\end{tabular}

The life condition of plants was estimated by V.A. Alekseyev as fully healthy. The average life expectancy of the needles is 3 years. All plants are located in sufficiently illuminated places, are characterized by regular seeding, and have no damage from Siberian cedar hermes (Pineus cembrae). There is also no damage from diseases commonly affecting pine trees: snow mold (snow schutte, Phlacidium infestans fungus) and bubble rust pine (Cronartium ribicola fungus).

The examples of photos of investigated plants are presented in Figure 1.

Characteristics of Pinus pumila (Pall.) Regel strobiles and seeds of local reproduction in the Botanical Garden of Peter the Great (St. Petersburg), SES "Otradnoe" (Leningrad region), from the natural population in the vicinity of Yuzhno-Sakhalinsk and Transbaikalia are presented in Table 2.

Digital X-ray images of Pinus pumila are presented in Figures 2-6. 


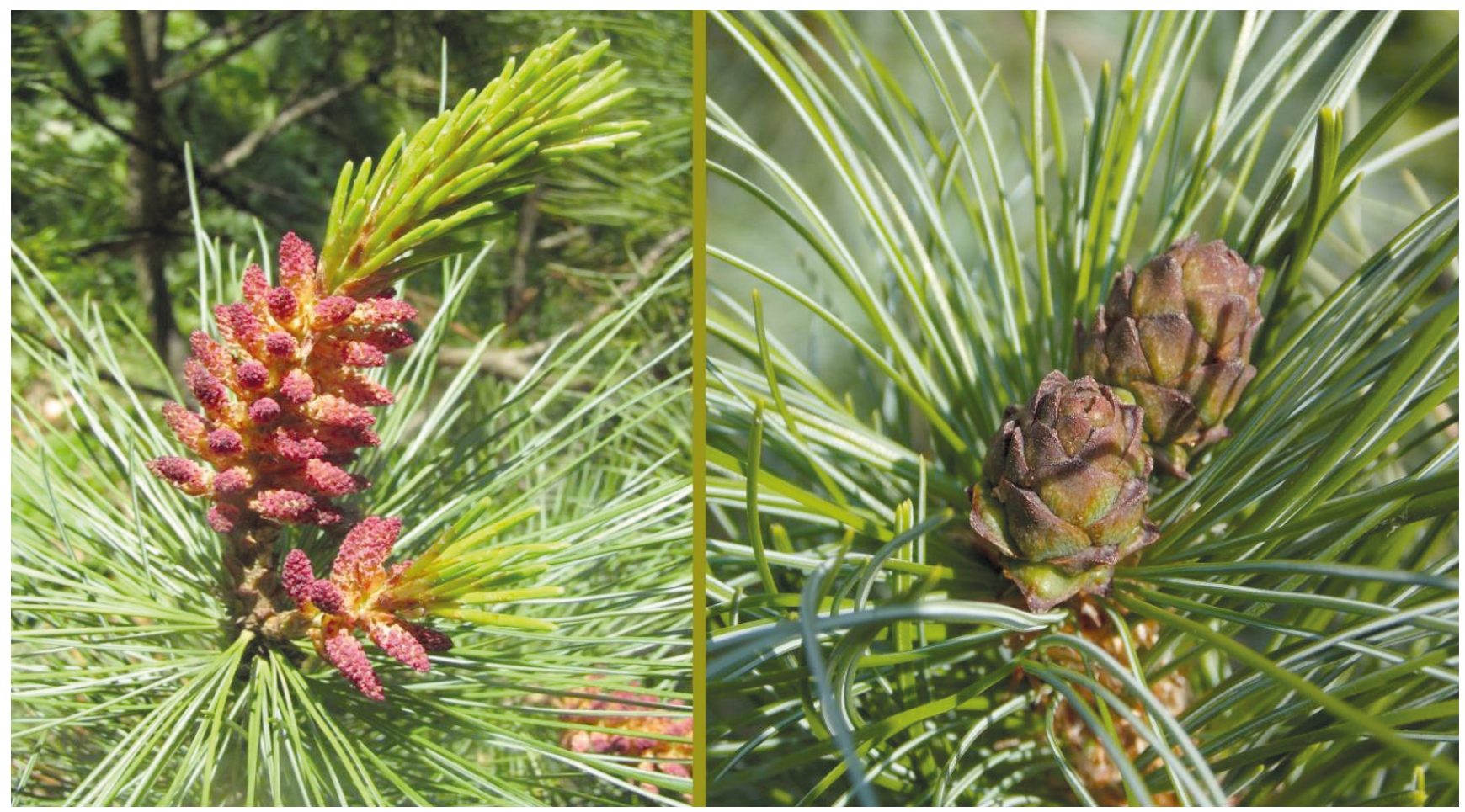

Fig. 1. Pinus pumila at Botanical Garden of Peter the Great. Microstrobiles during the pollen dispersion period, site 98,05 th June, 2018. Young strobiles, site 71. 28th August 2018.

Table 2. Characteristics of Pinus pumila (Pall.) Regel strobiles and seeds of local reproduction in the Botanical Garden of Peter the Great (St. Petersburg), SES "Otradnoe" (Leningrad region), from the natural population in the vicinity of YuzhnoSakhalinsk and Transbaikalia (Barguzinsky State Natural Biosphere Reserve)

\begin{tabular}{|c|c|c|c|c|c|}
\hline \multirow[b]{2}{*}{ Sample } & \multicolumn{5}{|c|}{ Growth sites } \\
\hline & $\begin{array}{l}\text { Vicinity of } \\
\text { Yuzhno- } \\
\text { Sakhalinsk }\end{array}$ & $\begin{array}{l}\text { Botanical Garden } \\
\text { of Peter the Great, } \\
\text { site } 71\end{array}$ & $\begin{array}{c}\text { Botanical Garden } \\
\text { of Peter the Great, } \\
\text { site } 98\end{array}$ & $\begin{array}{l}\text { SES } \\
\text { "Otradnoe", } \\
\text { No. } 4\end{array}$ & $\begin{array}{c}\text { Transbaikalia } \\
\text { Barguzinsky State } \\
\text { Natural Biosphere } \\
\text { Reserve }\end{array}$ \\
\hline Date of gathering & 10.2016 & 10.09 .2018 & 10.09 .2018 & 05.09 .2018 & 09.2019 \\
\hline Average weight of 1 cone, $g$ & 7.25 & 10.08 & 6.74 & 7.58 & 8.03 \\
\hline Average length of 1 cone, mm & 45.95 & 46.77 & 42.32 & 56.37 & 48.29 \\
\hline Average width of 1 cone, $\mathrm{mm}$ & 28.45 & 30.19 & 23.90 & 29.45 & 27.13 \\
\hline Average quantity of seeds in 1 cone & 44 & 24 & 31 & 32 & 40 \\
\hline Average weight of seed scales, g & 3.73 & 5.82 & 3.66 & 4.07 & 3.80 \\
\hline Weight of 1000 seeds, g & 80.55 & 177.28 & 99.35 & 109.69 & 101.46 \\
\hline
\end{tabular}

As can be seen in Figures 2-6, the percentage of unformed seeds is small and does not exceed $11 \%$. It is obvious that the low germination of seeds is largely due to the unformed embryo. The results of software processing of Pinus pumila seed digital images are shown in Table 3.

As can be seen from Table 3, the best characteristics of individual seed structures and organs were shown by samples taken from trees growing at site 71 of the Komarov Botanical Institute RAS. These samples had a high index of embryo area of $4.19 \pm 0.49 \mathrm{~mm}^{2}$, a maximum ratio of the areas of embryo to thalus of $60.95 \pm 7.45 \%$, a high index of endosperm area of $23.93 \pm 1.24 \mathrm{~mm}^{2}$, and a maximum relative embryo area of $9.45 \pm 1.17 \%$. The seed sample from Yuzhno-Sakhalinsk was characterized by a minimum embryo/thalus area ratio of $47.02 \pm 4.48 \%$ and a low index of relative seed cover area of $33.30 \pm 0.91 \%$. Despite the fact that the sample from Transbaikalia was characterized by maximum values of parameters such as the embryo area $\left(6.05 \pm 0.06 \mathrm{~mm}^{2}\right)$, the maximum area of the endosperm $\left(33.27 \pm 2.95 \mathrm{~mm}^{2}\right)$ and the maximum ratio of average brightness of embryo to the average 


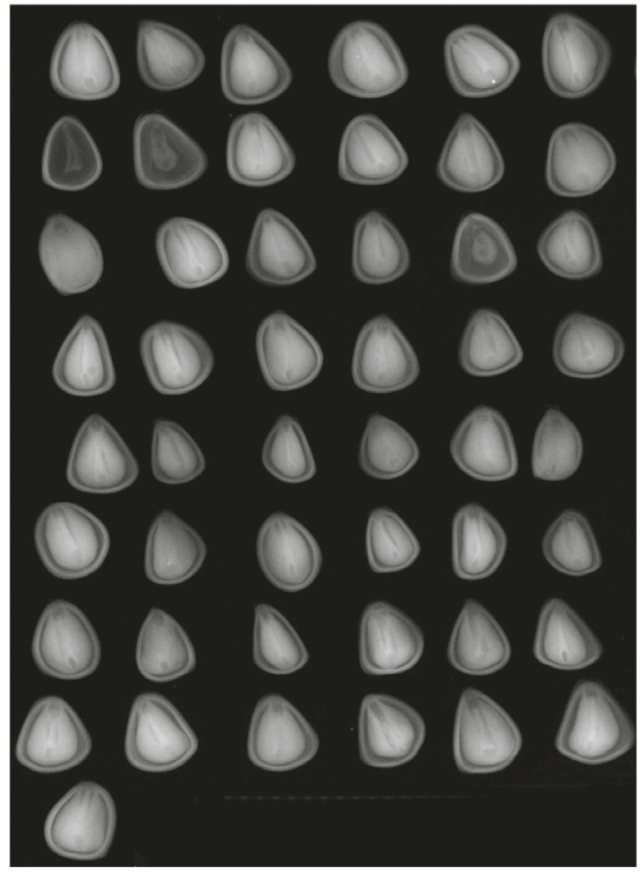

A

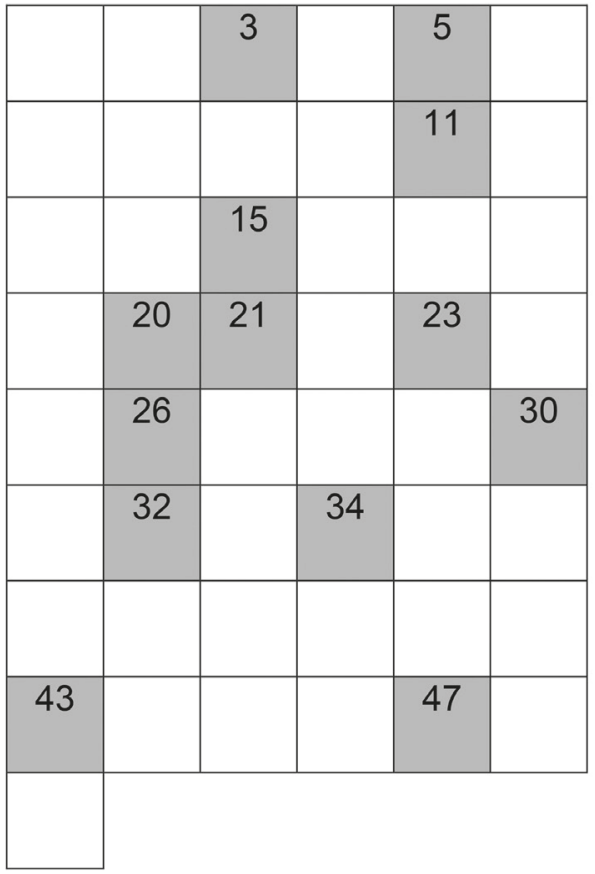

B

Fig. 2. X-ray images (A) and germination results (B) of Pinus pumila seeds collected in South Sakhalin, YuzhnoSakhalinsk in September 2016. Gray marks the germinated seeds, numbering seeds from 01 to 49 from left to right and from top to bottom.

Table 3. Results of software processing of digital images of Pinus pumila (Pall.) Regel seeds of local reproduction in the Botanical Garden of Peter the Great (St. Petersburg), SES “Otradnoe” (Leningrad region), and from the natural population in the vicinity of Yuzhno-Sakhalinsk and Transbaikalia (Barguzinsky State Natural Biosphere Reserve)

\begin{tabular}{|c|c|c|c|c|c|c|}
\hline \multirow[b]{2}{*}{ No } & \multirow[b]{2}{*}{ Parameters } & \multicolumn{5}{|c|}{ Growth sites } \\
\hline & & $\begin{array}{l}\text { Vicinity of } \\
\text { Yuzhno- } \\
\text { Sakhalinsk }\end{array}$ & $\begin{array}{c}\text { Botanical Garden } \\
\text { of Peter the Great, } \\
\text { site } 71\end{array}$ & $\begin{array}{l}\text { Botanical Garden } \\
\text { of Peter the Great, } \\
\text { site } 98\end{array}$ & $\begin{array}{c}\text { SES } \\
\text { "Otradnoe", } \\
\text { No. } 4\end{array}$ & $\begin{array}{l}\text { Transbaikalia } \\
\text { Barguzinsky State } \\
\text { Natural Biosphere } \\
\text { Reserve named } \\
\text { after K. A. Zabelin }\end{array}$ \\
\hline 1 & Embryo area, $\mathrm{mm}^{2}$ & $3.06 \pm 0.31$ & $4.19 \pm 0.49$ & $3.61 \pm 0.57$ & $2.65 \pm 0.34$ & $6.05 \pm 0.84$ \\
\hline 2 & $\begin{array}{l}\text { Ratio of the areas of embryo to } \\
\text { thalus, } \%\end{array}$ & $47.02 \pm 4.48$ & $60.95 \pm 7.45$ & $59.45 \pm 9.37$ & $48.35 \pm 5.60$ & $45.61 \pm 6.05$ \\
\hline 3 & $\begin{array}{l}\text { Embryo ellipse index, relative } \\
\text { units }\end{array}$ & $0.90 \pm 0.07$ & $0.89 \pm 0.08$ & $0.82 \pm 0.09$ & $0.87 \pm 0.08$ & $0.95 \pm 0.06$ \\
\hline 4 & Area of the endosperm, $\mathrm{mm}^{2}$ & $22.57 \pm 0.99$ & $23.93 \pm 1.24$ & $20.55 \pm 1.59$ & $19.08 \pm 0.92$ & $33.27 \pm 2.95$ \\
\hline 5 & Relative area of seed cover, $\%$ & $33.30 \pm 0.91$ & $46.38 \pm 2.75$ & $50.97 \pm 3.32$ & $50.62 \pm 2.00$ & $24.59 \pm 1.27$ \\
\hline 6 & $\begin{array}{l}\text { Relative area of } \\
\text { the endosperm \% }\end{array}$ & $66.70 \pm 0.91$ & $53.62 \pm 2.75$ & $49.03 \pm 3.32$ & $49.38 \pm 2.00$ & $58.53 \pm 3.66$ \\
\hline 7 & Relative area of the embryo, $\%$ & $9.05 \pm 0.81$ & $9.45 \pm 1.17$ & $8.68 \pm 1.34$ & $6.83 \pm 0.82$ & $7.67 \pm 1.03$ \\
\hline 8 & $\begin{array}{l}\text { Ratio of average brightness } \\
\text { of embryo to the average } \\
\text { brightness of a projection of } \\
\text { seed, relative units }\end{array}$ & $1.34 \pm 0.10$ & $1.29 \pm 0.11$ & $1.09 \pm 0.13$ & $1.12 \pm 0.10$ & $1.44 \pm 0.09$ \\
\hline 9 & Fullness of seeds, $\%$ & 94 & 92 & 89 & 93 & 89 \\
\hline 10 & Absolute germination, $\%$ & 28.2 & 42.2 & 32.1 & 34.5 & 32,3 \\
\hline 11 & Soil germination, $\%$ & 26.5 & 38.8 & 28.6 & 32.1 & 28,6 \\
\hline 12 & Seed viability (TZ), \% & 82 & 79 & 77 & 80 & 70 \\
\hline
\end{tabular}




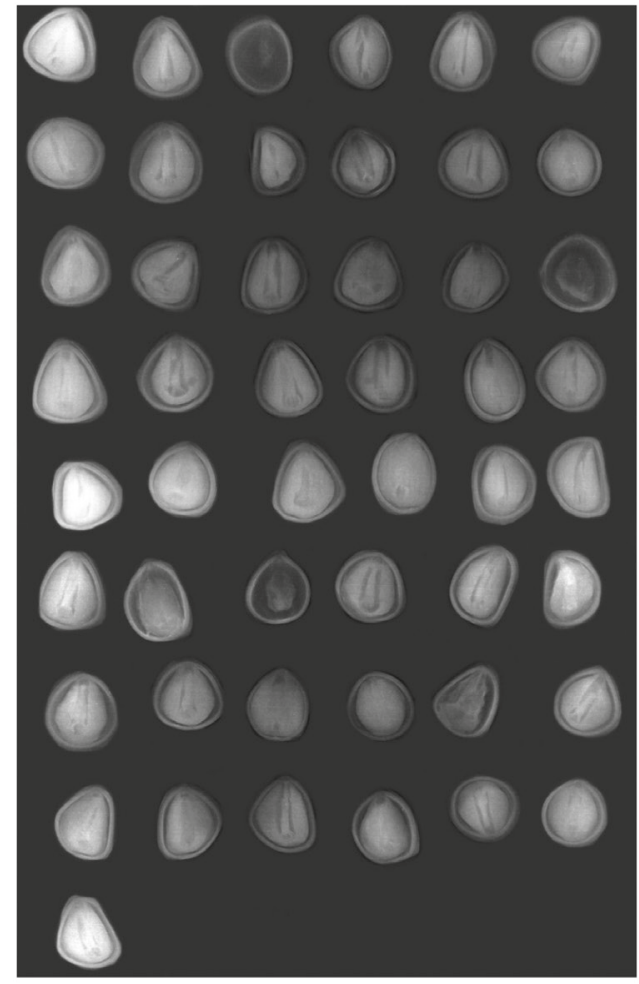

A

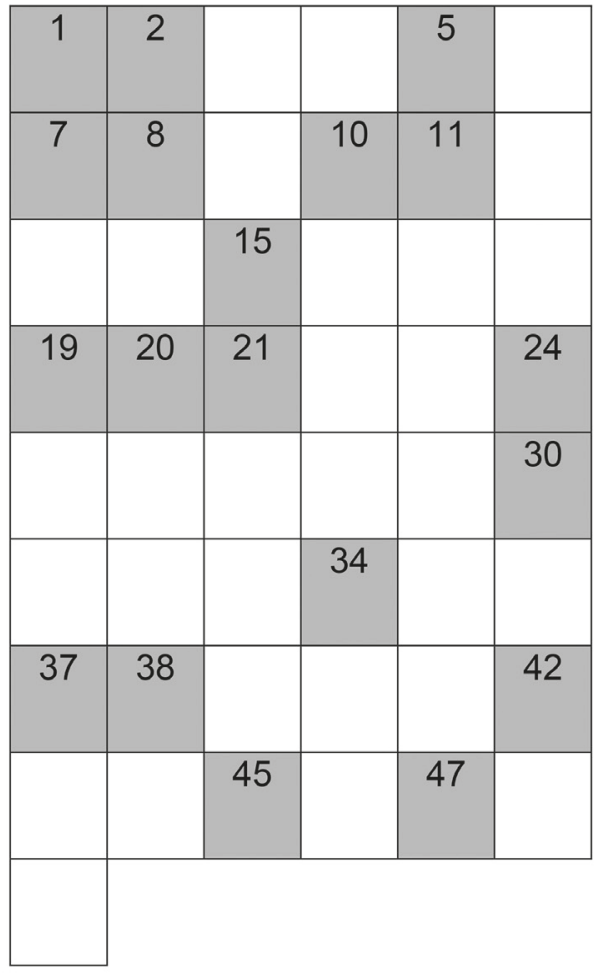

B

Fig. 3. X-ray images (A) and germination results (B) of Pinus pumila seeds collected in site 71 of the Komarov Botanical Institute RAS in September 2018. Gray marks the germinated seeds, numbering seeds from 01 to 49 from left to right and from top to bottom.

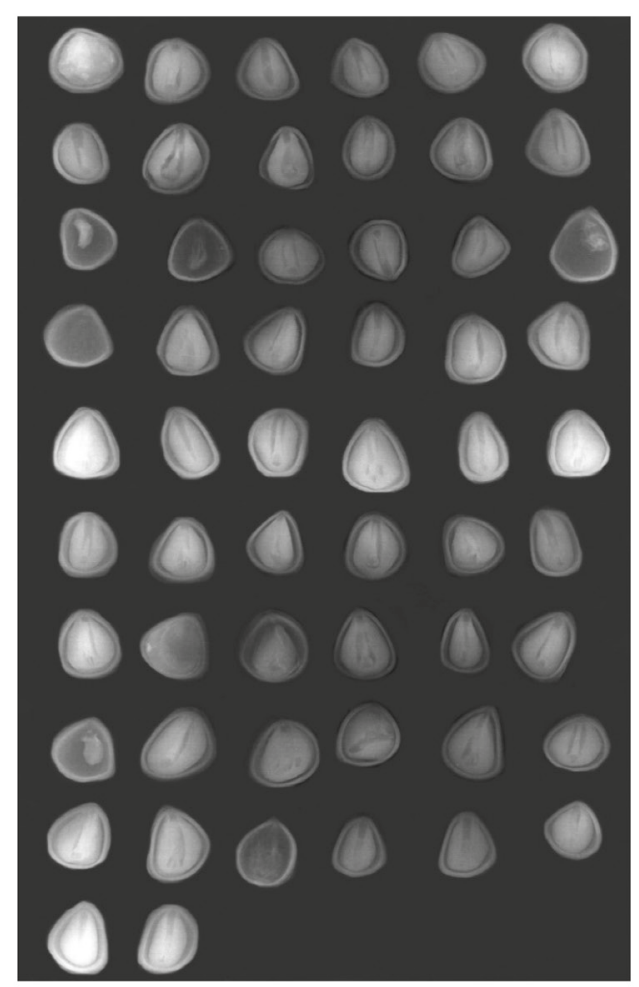

A

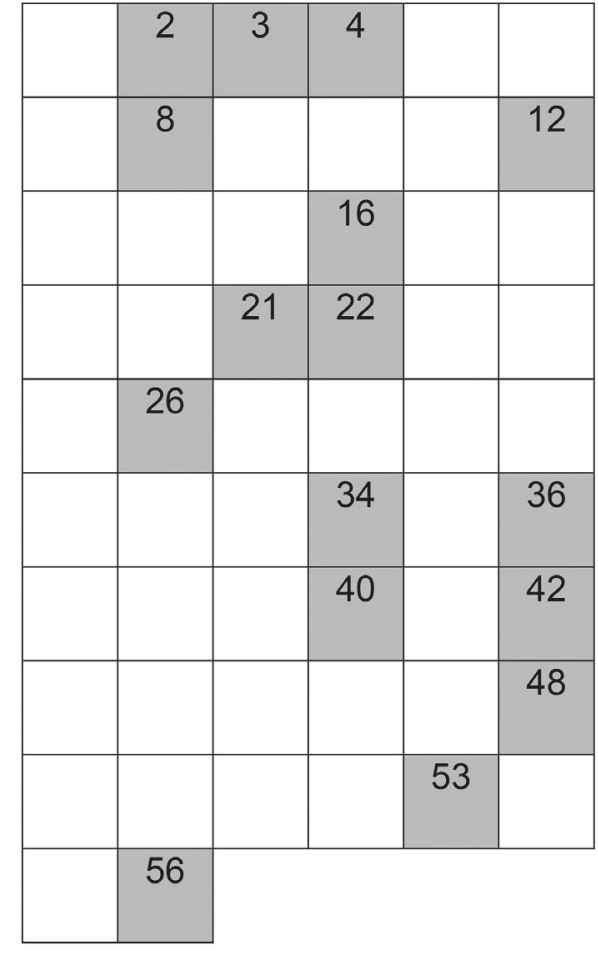

B

Fig. 4. X-ray images (A) and germination results (B) of Pinus pumila seeds collected in site 98 of the Komarov Botanical Institute RAS in September 2018. Gray marks the germinated seeds, numbering seeds from 01 to 56 from left to right and from top to bottom. 


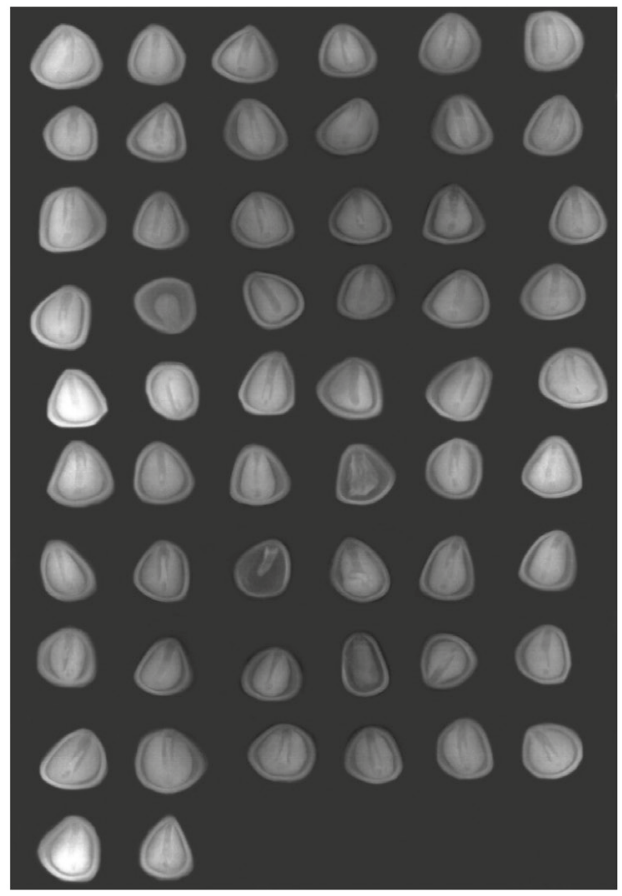

A

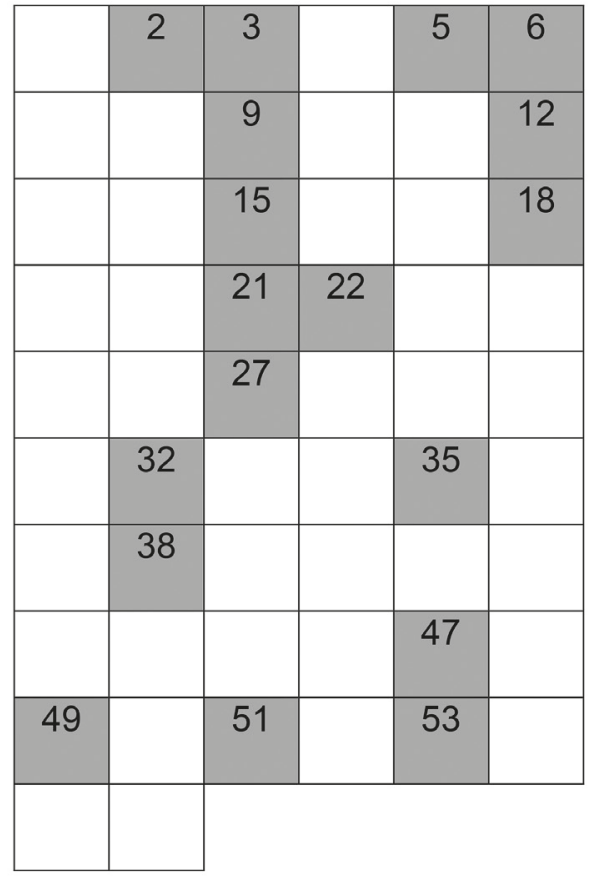

B

Fig. 5. X-ray images (A) and germination results (B) of Pinus pumila seeds collected in No. 4 of SES "Otradnoe" in September 2018. Gray marks the germinated seeds, numbering seeds from 01 to 56 from left to right and from top to bottom.

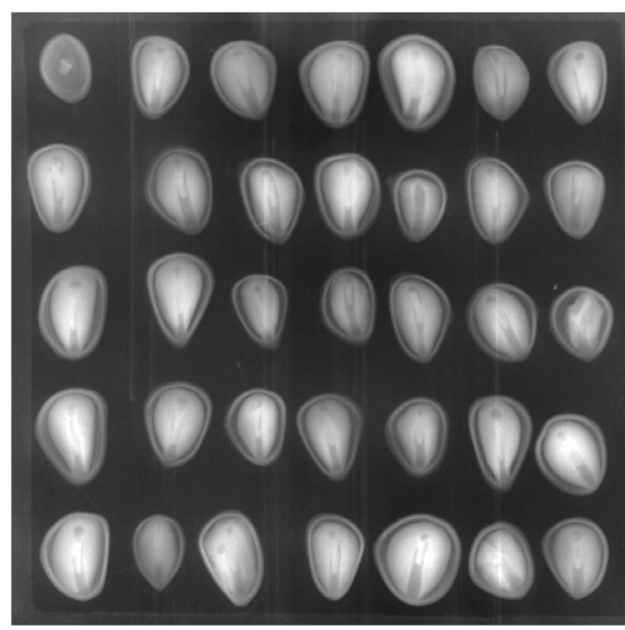

A

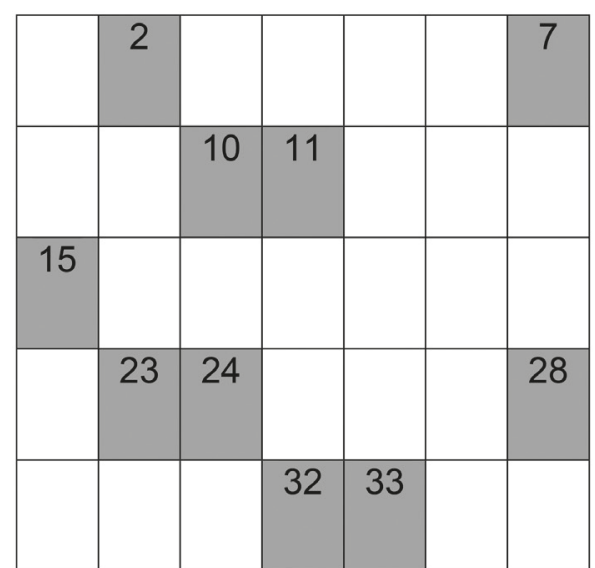

B

Fig. 6. X-ray images (A) and germination results (B) of Pinus pumila seeds collected in Transbaikalia Barguzinsky State Natural Biosphere Reserve named after K. A. Zabelin in September 2019. Gray marks the germinated seeds, numbering seeds from 01 to 35 from left to right and from top to bottom.

brightness of a projection of seed $(1.44 \pm 0.09$, relative units), the absolute and soil germination of the sample was low: 32.3 and $28.6 \%$, respectively. We assume that Pinus pumila seeds from Transbaikalia collected in 2019 were physiologically not yet ripe.

Correlations analysis of characteristics of digital Xray images and seed germination revealed the following results: there are correlations between the ellipse factor of the embryo and seed germination $(r=0.13)$. Correlations are significant by $\mathrm{p}<0.05$. The ellipse factor of the embryo may show a harmony of embryogenic development.

Dependence of absolute germination on the ratio of the areas of embryo to thalus is shown in Figure 7.

The fact of the greatest harmonization of seed development in site 71 of the BIN RAS and the smallest 
$\%$

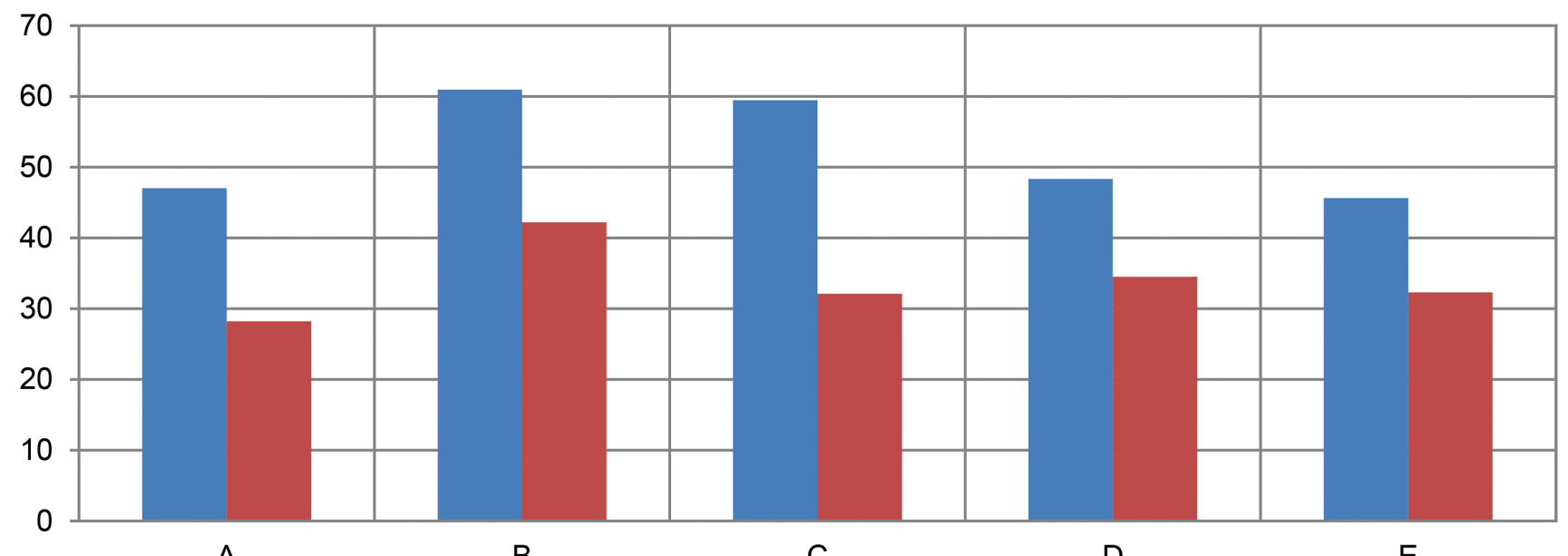

A

B

C

E

\section{Sample}

- Ratio of the areas embryo to thalus, $\%$

- Absolute germination, \%

Fig. 7. Ratio of the areas of embryo to thalus and absolute germination of Pinus pumila seeds. A - Vicinity of Yuzhno-Sakhalinsk, B - Botanical Garden of Peter the Great, site 71, C - Botanical Garden of Peter the Great, site 98, D - SES "Otradnoe", No. 4, E - Transbaikalia Barguzinsky State Natural Biosphere Reserve named after K. A. Zabelin.

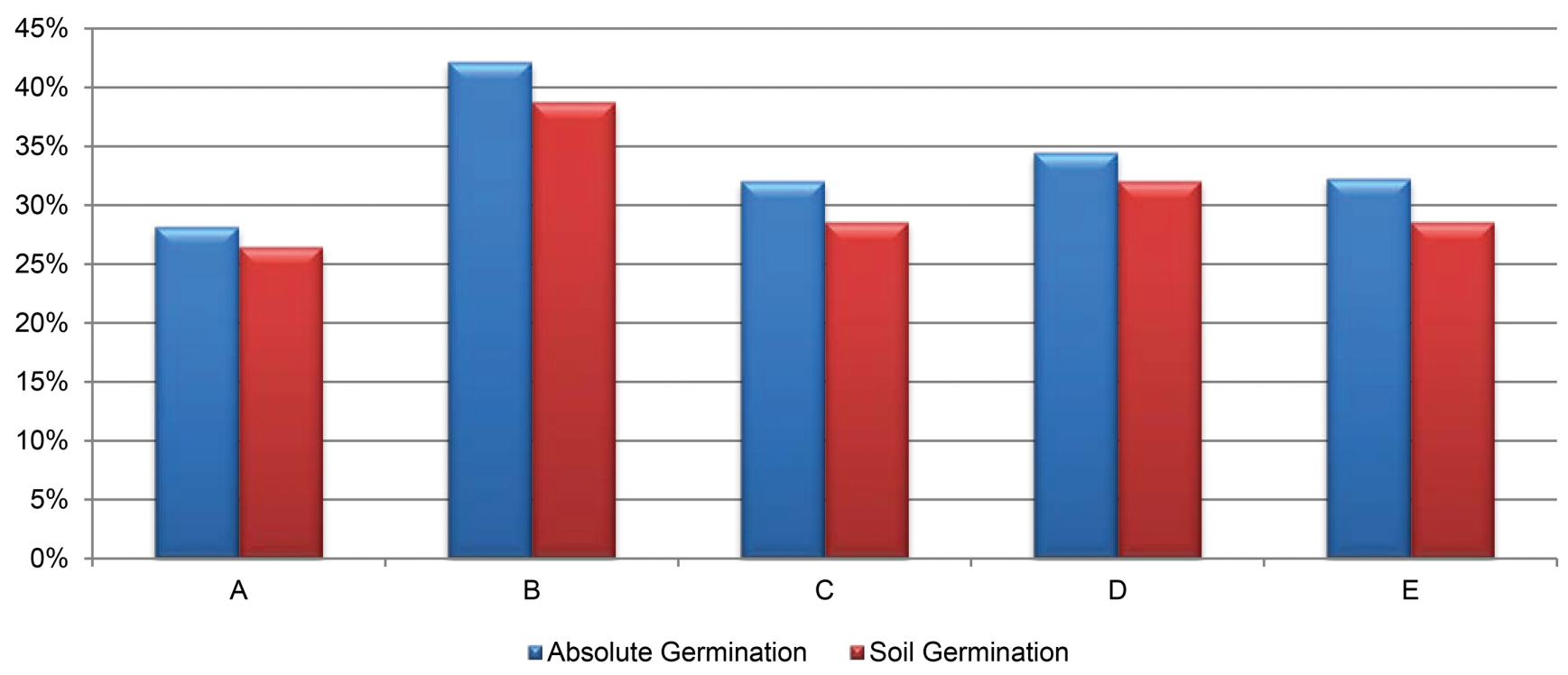

Fig. 8. Absolute and soil germination of Pinus pumila seeds. A — Vicinity of Yuzhno-Sakhalinsk, B - Botanical Garden of Peter the Great, site 71, C - Botanical Garden of Peter the Great, site 98, D - SES "Otradnoe", No. 4, E - Transbaikalia Barguzinsky State Natural Biosphere Reserve named after K. A. Zabelin.

in samples from Yuzhno-Sakhalinsk is confirmed by the data of absolute and soil germination (Figure 8).

Dynamics of Pinula pumila seeds germinating are presented in Figure 9.

Seeds taken from site 71 of the Botanical Garden of Peter the Great were characterized by earlier germination, in the range from 25 to 40 days, while seeds taken from South Sakhalin began to germinate only on the 35th day, then germination dynamics gradually increased up to the end of measurement (60 days). The low germina- tion rate and slow germination progress of seeds from South Sakhalin is partly due to their long storage. The soil germination rate of fresh seeds (sown in 2017) under the same conditions was $41 \%$ (Karamysheva et al., 2019 C). The data obtained allow us to say that storage for 2 years at $0+3^{\circ} \mathrm{C}$ significantly reduces the soil germination of Pinus pumila seeds. This is also true for other species of the Pinaceae family (Teplykh et al., 2018; Sidor et al., 2011).

The majority of seeds collected in Transbaikalia sprouted in the same period as the seeds collected in the 

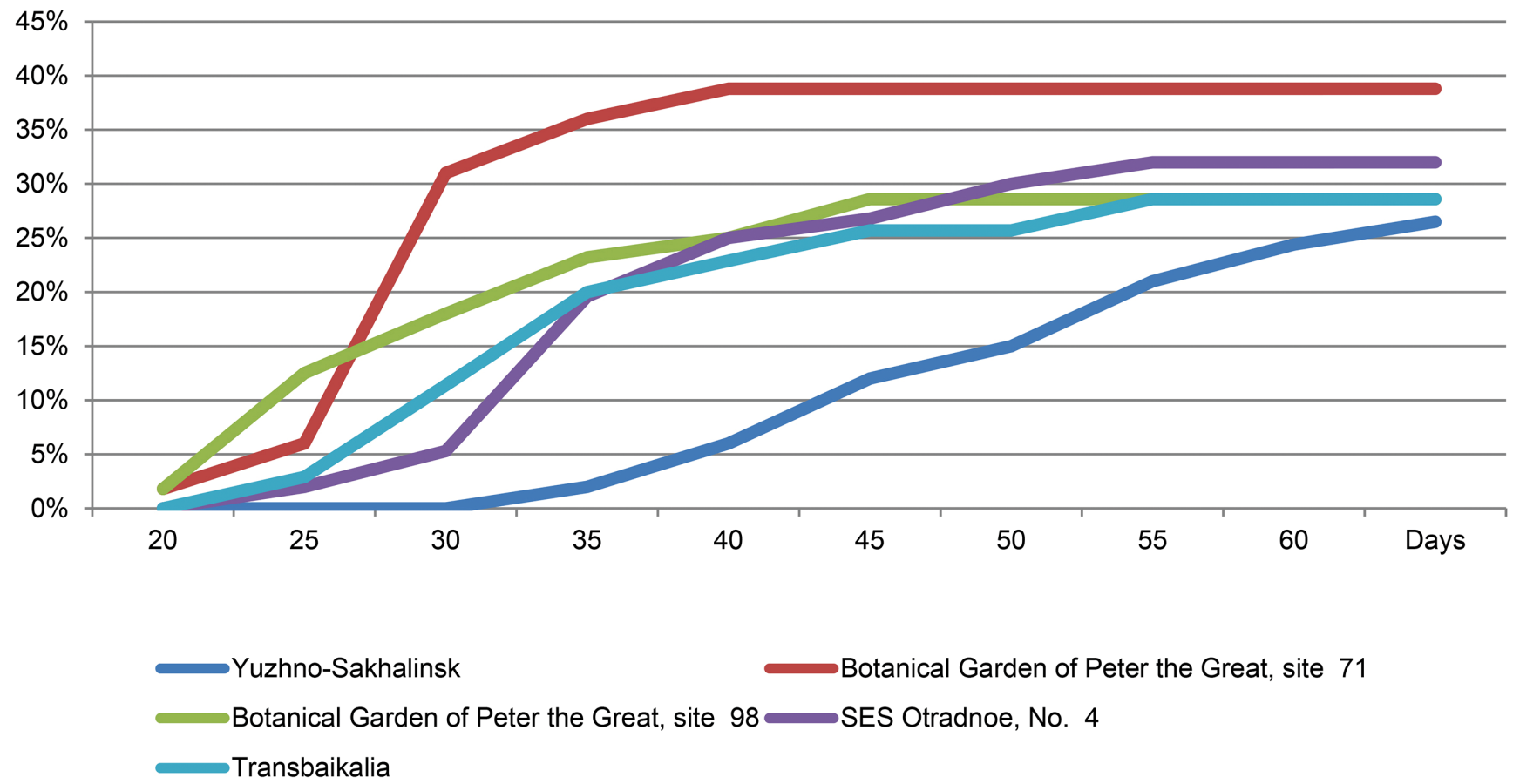

Fig. 9. Dynamics of Pinula pumila seed germination.

Table 4. Biometric indicators of Pinus pumila seedlings 100 days after seed sowing

\begin{tabular}{c|l|c|c|c|c|c}
\hline \multirow{2}{*}{ No } & \multicolumn{1}{|c|}{ Parameters } & \multicolumn{5}{|c}{ Places of growth } \\
\cline { 3 - 7 } & & $\begin{array}{c}\text { Vicinity of } \\
\text { Yuzhno- } \\
\text { Sakhalinsk }\end{array}$ & $\begin{array}{c}\text { Botanical Garden } \\
\text { of Peter the Great, } \\
\text { site 71 }\end{array}$ & $\begin{array}{c}\text { Botanical Garden } \\
\text { of Peter the Great, } \\
\text { site 98 }\end{array}$ & $\begin{array}{c}\text { SES Otradnoe”, } \\
\text { No. 4 }\end{array}$ & $\begin{array}{c}\text { Transbaikalia } \\
\text { Barguzinsky State } \\
\text { Natural Biosphere } \\
\text { Reserve }\end{array}$ \\
\hline 1 & Average height, $\mathrm{mm}$ & $32.02 \pm 4.16$ & $54.46 \pm 4.66$ & $53.41 \pm 4.48$ & $46.40 \pm 4.05$ & $45.54 \pm 3.91$ \\
\hline 2 & Average root length, $\mathrm{mm}$ & $64.06 \pm 7.27$ & $73.51 \pm 9.34$ & $78.79 \pm 9.58$ & $91.60 \pm 11.33$ & $76.65 \pm 8.92$ \\
\hline 3 & Average number of lateral roots & $2.67 \pm 0.22$ & $1.98 \pm 0.20$ & $5.19 \pm 0.45$ & $3.80 \pm 0.32$ & $3.35 \pm 0.30$ \\
\hline 4 & Average needle length, $\mathrm{mm}$ & $27.05 \pm 4.05$ & $27.47 \pm 5.56$ & $33.78 \pm 4.21$ & $23.42 \pm 3.28$ & $34.06 \pm 5.11$ \\
\hline
\end{tabular}

Botanical Garden of Peter the Great and the SES "Otradnoe", though they have a lower soil germination rate.

Biometric parameters of Pinus pumila seedlings were measured once 100 days after seed sowing. They are presented in Table 4 .

Table 4 illustrates the maximum average height of plants in Pinus pumila seedlings obtained at site 71 of the Botanical Garden of Peter the Great and the minimum in seedlings obtained from seeds from YuzhnoSakhalinsk. Seedlings from Yuzhno-Sakhalinsk were also characterized by a minimum value of average root length, $\mathrm{mm}$. The minimum number of lateral roots in seedlings from the site 71 may indicate the peculiarities of root system formation in the given sample-the tap root prevails. Seedlings grown from seeds collected in Transbaikalia on the main biometric indicators are slightly inferior to seedlings from the Botanical Garden of Peter the Great and the SES "Otradnoe".

\section{Conclusions}

As a result of the analysis of characteristics of digital X-ray images of Pinus pumila seeds, their weight and sowing qualities, it was established that the sample of seeds from site 71 of the Botanical Garden of Peter the Great was characterized by the maximum embryo area: $4.19 \pm 0.49 \mathrm{~mm}^{2}$, maximum ratio of the areas of embryo to thalus: $60.95 \pm 7.45 \%$, maximum endosperm area $23.93 \pm 1.24 \mathrm{~mm}^{2}$, and maximum relative area of the embryo: $9.45 \pm 1.17 \%$. The same sample was characterized by a maximum weight of 1000 seeds and a maximum absolute and soil germination, compared to other samples. Despite the fact that the sample from Transbaikalia was characterized by maximum values of parameters such as embryo area $\left(6.05 \pm 0.06 \mathrm{~mm}^{2}\right)$, the maximum endosperm area $\left(33.27 \pm 2.95 \mathrm{~mm}^{2}\right)$ and the maximum ratio of average brightness of embryo to the average bright- 
ness of a projection of seed ( $1.44 \pm 0.09$, relative units), the absolute germination and soil germination of the sample are slightly lower than those of seeds from the Botanical Garden of Peter the Great. In all likelihood, the seeds of Pinus pumila from Transbaikalia collected in 2019 were physiologically not yet ripe.

Correlations analysis of characteristics of digital $\mathrm{X}$-ray images and seed germination revealed correlations between ellipse factor of the embryo and seed germination $(\mathrm{r}=0.13)$.

The work made it possible to conclude that the method of microfocus X-ray radiography in combination with automatic analysis of digital X-ray images can be an effective tool for quickly determining the quality of dwarf Siberian pine seeds.

The obtained data showed that Pinus pumila seeds collected from plants introduced in northwestern Russia by most parameters are not inferior to and even exceed seeds from natural growth sites. This encourages creation of a Pinus pumila population independent of natural growth sites for use in parks and urban gardening in northwestern Russia, in particular in St. Petersburg and Leningrad regions.

\section{References}

Alekseev, V. A. 1989. Diagnosing the life state of trees and forest stands. Lesovedenie 4:51-57. (In Russian)

Alekseychuk, G. N. and Laman, N. A. 2005. Physiological quality of crop seeds and methods of their evaluation. $48 \mathrm{p}$. Minsk. https://doi.org/10.13140/RG.2.2.36109.64485 (In Russian)

Al Turki, T. A. and Baskin, C. C. 2017. Determination of seed viability of eight wild Saudi Arabian species by germination and X-Ray tests. Saudi Journal of Biological Sciences 24:822-829. https://doi.org/10.1016/j.sjbs.2016.06.009

Arkhipov, M. V., Dem'yanchuk, A. M., Velikanov, L. P., Potrakhov, N. N., Gryaznov, A. Yu., and Potrakhov, E. N. 2009. Russian Patent No. 85292, MPC A01C 1/02. Device for X-ray diagnostics of grain and seeds. Bulletin No. 22. (In Russian)

Arkhipov, M. V., Priyatkin, N. S., and Bondarenko, A. S. 2013. Application of soft-beam $\mathrm{x}$-ray and gas-discharge visualization methods for assessment of European spruce seed quality. Izvestija Sankt-Peterburgskogo gosudarstvennogo agrarnogo universiteta 31:62-66. (In Russian)

Arkhipov, M.V., Priyatkin, N.S., Gusakova, L.P., Potrakhov, N. N., Gryaznov, A.Y., Bessonov, V.B., Obodovskii, A.V., and Staroverov, N.E. 2019. X-Ray computer methods for studying the structural integrity of seeds and their importance in modern seed science. Technical Physics 64(4):582-592. https://doi.org/10.1134/ S1063784219040030

Belcher, E.W.Jr. 1977. Radiographic analysis of agriculture and forest tree seeds. Document prepared for the Seed $\mathrm{X}$-ray Technology Committee of the association of official seed analysts, Boise, Idaho. 31:1-29.

Duffield, J. W. 1973. New techniques for reading seed radiographs save time. Tree Plant, Notes 24:14.

Filippova, E. V., Bobrinev, V.P., and Pak, L. N. 2015. Features of the biology of cedar stlanik (Pinus pumila) in the north of Transbaikalia. Vestnik Zabajkal'skogo gosudarstvennogo universiteta. Nauki o Zemle 6(121):44-49. (In Russian)

Goodman, R. C., Jacobs, R. C., and Karrfalt, R. P. 2005. Evaluating desiccation sensitivity of Quercus rubra acorns using
X-Ray image analysis. Canadian Journal of Forest Research 35:2823-2831. https://doi.org/10.1139/X05-209

Hampton, J. G. and Tekrony, D. M. 1995. Handbook of Vigor Test Methods. Vigour Test Committee 3rd Edition, ISTA, Zurich, Switzerland. $117 \mathrm{p}$.

Kamra, S. K. 1976. Use of X-ray radiography for studying seed quality in tropical forestry. Studia Forestalia Suecica 13:1-34.

Karamysheva, A.V., Trofimuk, L.P., Priyatkin, N.S., Arkhipov, M.V., Gusakova, L.P., Potrakhov, N. N., BesSonov, V. B., and Shhukina, P. A. 2019a. Microfocus X-Ray radiography studies of seed fullness of Platycladus orientalis and Thuja sutchuenensis (Cupressaceae) for predicting seed sowing quality. Rastitel'nye resursy 55(4):501-515. https://doi.org/10.1134/S0033994619040058 (In Russian)

Karamysheva, A., Trofimuk, L., Priyatkin, N., Arkhipov, M., and Sshukina, P. 2019b. Comparative characteristics and germination of Pinus sibirica seeds collected from places of natural growth and in the St. Petersburg Botanical garden of Peter the Great. IOP Conference Series: Earth and Environmental Science 316:012017. https://doi. org/10.1088/1755-1315/316/1/012017

Karamysheva, A. V., Firsov, G. A., Trofimuk, L. P., and Orlova, L. V. 2019c. Peculiarities and methods of seed propagation of dwarf Siberian pine (Pinus pumila (Pall.) Regel, Pinaceae) at Saint-Petersburg. Vestnik Udmurtskogo universiteta. Serija Biologija. Nauki o Zemle 29(2):181-189. https://doi. org/10.35634/2412-9518-2019-29-2-181-189 (In Russian)

McMillan-Browse, P. 1985. Hardy woody plants from seed. Grower Books. 163 p.

Orlova, L. V., Firsov G. A., Trofimuk, L. P., and Karamysheva, A. V. 2019. Siberian dwarf pine (Pinus pumila (Pall.) Regel, Pinaceae) - history of study, the current state in the botanical gardens of Saint Petersburg and the perspectives of its use in greening in the North-West of Russia. Hortus Botanicus 14:37-52. https://doi.org/10.15393/ j4.art.2019.6064 (In Russian)

Priyatkin, N. S., Butenko, O. Yu., Shabunin, D. A., Arkhipov, M. V., Gusakova, L. P., Boitsov, A. A., Potrakhov, N. N., Staroverov, N. E., and Savvina, K. A. 2018. Examination of digital X-ray and gas discharge characteristics of English oak acorns (Quercus robur L.) for assessment of their sowing qualities. Trudy Sankt-Peterburgskogo NII Lesnogo hozjajstva 2:4-17. https://doi.org/10.21178/2079-6080.2018.2.4 (In Russian)

Sahlen, K., Bergsten, U., and Wiklund, K. 1995. Determination of viable and dead Scots pine seeds of different anatomical maturity after freezing using IDX method. Seed Science and Technology 23:405-414.

Seed of trees and shrubs. Methods for determination of viability. 1995. GOST 13056.7-93. 40 p. (In Russian)

Sidor, A. I., Kovalevich, A. I., Konchits, A. P., Luferova, N. S., and Maltseva, L. V. 2011. Study of the qualitative parameters of Scots pine seeds during long-term storage. Lesnoe $i$ okhotnich'e khoziaistvo 11:22-32. (In Russian)

Simak, M. and Gustafsson, A. 1953. X-ray photography and sensitivity in forest tree species. Hereditas 39:458-468. https://doi.org/10.1111/j.1601-5223.1953.tb03430.x

Teplykh, A. A. and Prokhorova, E. V. 2018. The influence of the shelf life of spruce seeds on their technical characteristics germination rate. Vestnik Povolzhskogo gosudarstvennogo tekhnologicheskogo univepsiteta. Ser.: Les. Ekologiia. Prirodopol'zovanie 2(38):19-28. https://doi. org/10.15350/2306-2827.2018.2.19 (In Russian)

Tkachenko, K. G. 2016. X-ray method of determining the quality of reproductive diasporas and detecting pests in them. Materials of the All-Russian Conference with International Participation "Monitoring and Biological Methods of Control of Pests and Pathogens of Wood Plants: from Theory to Practice." Krasnoyarsk, ILSORAN, pp. 226-227. 